\title{
How can the orthopedic surgeon ensure optimal vitamin D status in patients operated for an osteoporotic fracture?
}

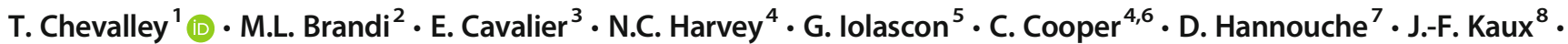 \\ A. Kurth ${ }^{9} \cdot$ S. Maggi ${ }^{10} \cdot$ G. Maier ${ }^{11} \cdot$ K. Papavasiliou ${ }^{12} \cdot$ N. Al-Daghri ${ }^{13} \cdot$ M. Sosa-Henríquez ${ }^{14,15} \cdot$ N. Suhm ${ }^{16}$. \\ U. Tarantino ${ }^{17} \cdot$ J.-Y. Reginster ${ }^{18} \cdot$ R. Rizzoli $^{1}$
}

Received: 8 February 2021 / Accepted: 9 April 2021

(C) The Author(s) 2021

\begin{abstract}
In this narrative review, the role of vitamin D deficiency in the pathophysiology, healing of fragility fractures, and rehabilitation is discussed. Vitamin D status can be assessed by measuring serum $25(\mathrm{OH})$-vitamin D level with standardized assays. There is a high prevalence of vitamin D insufficiency $(25(\mathrm{OH}) \mathrm{D}<50 \mathrm{nmol} / \mathrm{l}(\mathrm{i} . \mathrm{e} ., 20 \mathrm{ng} / \mathrm{mL}))$ or deficiency $(25(\mathrm{OH}) \mathrm{D}<25 \mathrm{nmol} / 1$ (i.e., 10 $\mathrm{ng} / \mathrm{mL})$ ) in patients with fragility fractures and especially in those with a hip fracture. The evidence on the effects of vitamin D deficiency and/or vitamin D supplementation on fracture healing and material osseointegration is still limited. However, it appears that vitamin D have a rather positive influence on these processes. The fracture liaison service (FLS) model can help to inform orthopedic surgeons, all caregivers, and fractured patients about the importance of optimal vitamin D status in the management of patients with fragility fractures. Therefore, vitamin D status should be included in Capture the Fracture $§$ program as an outcome of FLS in addition to dual-energy X-ray absorptiometry (DXA) and specific antiosteoporosis medication. Vitamin D plays a significant role in the pathophysiology and healing of fragility fractures and in rehabilitation after fracture. Correction of vitamin D deficiency should be one of the main outcomes in fracture liaison services.
\end{abstract}

Keywords Fragility fracture $\cdot$ Fracture healing $\cdot$ Fracture liaison service $\cdot$ Rehabilitation $\cdot$ Vitamin D

T. Chevalley

Thierry.chevalley@hcuge.ch

1 Service of Bone Diseases, Geneva University Hospitals and Faculty of Medicine, Geneva, Switzerland

2 Metabolic Bone Diseases Unit, Department of Surgery and Translational Medicine, University of Florence, Florence, Italy

3 Department of Clinical Chemistry, University of Liege, CHU de Liege, Liege, Belgium

4 MRC Lifecourse Epidemiology Unit, NIHR Southampton Biomedical Research Centre, University of Southampton, University Hospital Southampton NHS Foundation Trust, Southampton, UK

5 Department of Medical and Surgical Specialties and Dentistry, University of Campania “Luigi Vanvitelli”, Naples, Italy

6 UKNIHR Oxford Biomedical Research Centre, University of Oxford, Oxford, UK

7 Service of Orthopaedics and Trauma Surgery, Geneva University Hospitals and Faculty of Medicine, Geneva, Switzerland

8 Department of Physical Medicine and Rehabilitation, University and University Hospital of Liège, Liège, Belgium

9 Department of Orthopaedic and Trauma Surgery, Campus Kemperhof, Community Clinics Middle Rhine, Koblenz, Germany
10

11 Department of Orthopaedic and Rheumatological Rehabilitation, Rehazentrum am Meer, Bad Zwischenahn, Germany

12 3rd Orthopaedic Department, Aristotle University of Thessaloniki Medical School, Papageorgiou General Hospital, Thessaloniki, Greece

13 Chair for Biomarkers of Chronic Diseases, Biochemistry Department, College of Science King Saud University, Riyadh 11451, Saudi Arabia

14 University Institute of Investigation on Biomedical Sciences (IUIBMS), University of Las Palmas de Gran Canaria, Las Palmas de Gran Canaria, Canary Islands, Spain

15 Bone Metabolic Unit, Hospital University Insular, Las Palmas de Gran Canaria, Canary Islands, Spain

16 Department of Orthopaedic and Trauma Surgery, University Hospital Basel, Spitalstrasse 21, 4031 Basel, Switzerland

17 Department of Clinical Sciences and Translational Medicine, Faculty of Medicine and Surgery, Tor Vergata University of Rome, Via Montpellier 1, 00133 Rome, Italy

18 Department of Public Health, Epidemiology and Health Economics, University of Liège, Liège, Belgium 


\section{Introduction}

With the aging of the population, osteoporosis and fragility fractures represent a dramatic challenge for health burden and medical professionals. Hip fractures in particular with a 1-year excess mortality of at least $20 \%$ account for the high burden of osteoporosis in terms of morbidity and costs [1-3]. Thirty percent of these patients become permanently disabled, while $40 \%$ of them loose the ability to walk independently and $80 \%$ become dependent for the activities of daily living after the fracture $[4,5]$. Total fragility fractures in the largest five European Union (EU) countries and Sweden (EU6) are estimated to increase by $23 \%$ from 2.7 million in 2017 to 3.3 million on 2030 [5]. In EU6, an estimated 1.0 million quality-adjusted life years (QALYs) were lost in 2017 due to fragility fractures, and a $27 \%$ increase of the resulting annual fracture-related costs of 37.5 billion euros in 2017 is expected by 2030 [5].

Among the various risk factors for fragility fractures, vitamin D deficiency appears to play a significant role $[6,7]$. Vitamin D is a pleiotropic substance, with receptors and effects in a large variety of tissues [8]. Vitamin D deficiency is implicated in impaired muscle function and risk of falling [9, 10] and in calcium and phosphorus homeostasis [11]. Low calcifediol levels, hence vitamin D deficiency, are consistently found in patients with fragility fractures, including hip fractures $[12,13]$. In addition, vitamin D deficiency is associated with reduced mobility after hip fracture surgical repair [14].

In the present narrative review, the role of vitamin D deficiency in the pathophysiology and the recovery of fragility fractures is addressed, and the ways to detect and correct it, as available to the orthopedic surgeon, who is at the forefront of the problem, are discussed. Depending on the local structure, other specialties such as geriatrician in the frame of orthogeriatric units and metabolic bone diseases specialists are essential complements for the orthopedic surgeon in the early management of fractured patients.

\section{Methods}

An expert working group was convened in September 2020 under the auspices of the European Society for Clinical and Economic Aspects of Osteoporosis, Osteoarthritis and Musculoskeletal Diseases (ESCEO). This group, comprising expert clinicians of different medical specialties (orthopedic surgeons, physical and rehabilitation medicine (PRM) specialists, rheumatologists, endocrinologists, and geriatricians) and researchers, reviewed the literature and presented the current state of the art on the followings topics : (1) assessment of vitamin D status and the need for appropriate $25(\mathrm{OH})$-vitamin $\mathrm{D}[25(\mathrm{OH}) \mathrm{D}]$ measurements (when and how); (2) prevalence of vitamin D insufficiency/deficiency in patients admitted to the orthopedic ward; (3) role of vitamin D in fracture healing and material osseointegration; (4) supplementation with vitamin D during rehabilitation; (5) fracture liaison service for the optimal management of the vitamin D deficiency in patients with fragility fracture. This paper reflects the presentations and the discussions of the working group that reviewed the current evidence of vitamin $\mathrm{D}$ in the management of patients in the orthopedic ward for a fragility fracture. It is based on an extensive narrative literature review, focusing on the most robust evidence such as a series of recent meta-analyses of post fracture care, i.e., fracture repair, rehabilitation in relation with vitamin D status, which constituted the search criteria in PubMed. A special emphasis was given to the prevalence of vitamin $\mathrm{D}$ deficiency in the fractured people population and to the approach to correct it, as well as the critical role of Fracture Liaison Services in achieving this goal.

\section{Assessment of vitamin D status and the need for appropriate $25(\mathrm{OH})$-vitamin D measurements}

\section{Vitamin D metabolism}

Vitamin D3 (cholecalciferol) and D2 (ergocalciferol) are the two major forms of vitamin D and differ in the structure of their side chains. Vitamin D3 is the form of the vitamin synthesized by mammals. Both vitamin D3 and D2 may be obtained in small amounts from the diet, or in more significant quantities from fortified foods or vitamin supplements [15]. Dietary sources usually represent only $10-20 \%$ of total vitamin D $[16,17]$. Fatty fish, fish liver oil, and egg yolk naturally contain the highest concentrations of vitamin D $[18,19]$. Synthesis of vitamin D in the skin commences when 7-dehydrocholesterol absorbs UVB radiation with a wave length between 290 and $315 \mathrm{~nm}$ leading first to the formation of previtamin D3 which is further transformed in a more stable isomer, vitamin D3 [20] (Fig. 1). In the liver, vitamin $\mathrm{D}$ is hydroxylated by the enzyme CYP2R1 to 25-hydroxy-vitamin D (25(OH)D, calcifediol), which has a half-life of 3 weeks and circulates in the nanomolar range bound to vitamin $\mathrm{D}$ binding protein (VDBP) and albumin and as a free form. Subsequently, 25(OH)D is hydroxylated to bioactive 1,25-dihydroxy-vitamin $\mathrm{D}\left(1,25-(\mathrm{OH})_{2} \mathrm{D}\right.$,calcitriol) by the enzyme CYP27B1. This hydroxylation in the kidney (1alpha hydroxylase) is stimulated by PTH, IGF-I, a low calcium diet, low circulating calcium, or phosphate levels and inhibited by FGF23, 1,25- $(\mathrm{OH})_{2} \mathrm{D}$, and glucocorticoids. $1,25-(\mathrm{OH})_{2} \mathrm{D}$ has a shorter half-live of about $4 \mathrm{~h}$ and circulates in the picomolar range bound to VDBP with 10 - to 100 -fold lower affinity than $25(\mathrm{OH}) \mathrm{D}$. It interacts with vitamin D receptor (VDR) with genomic and non-genomic effects. 


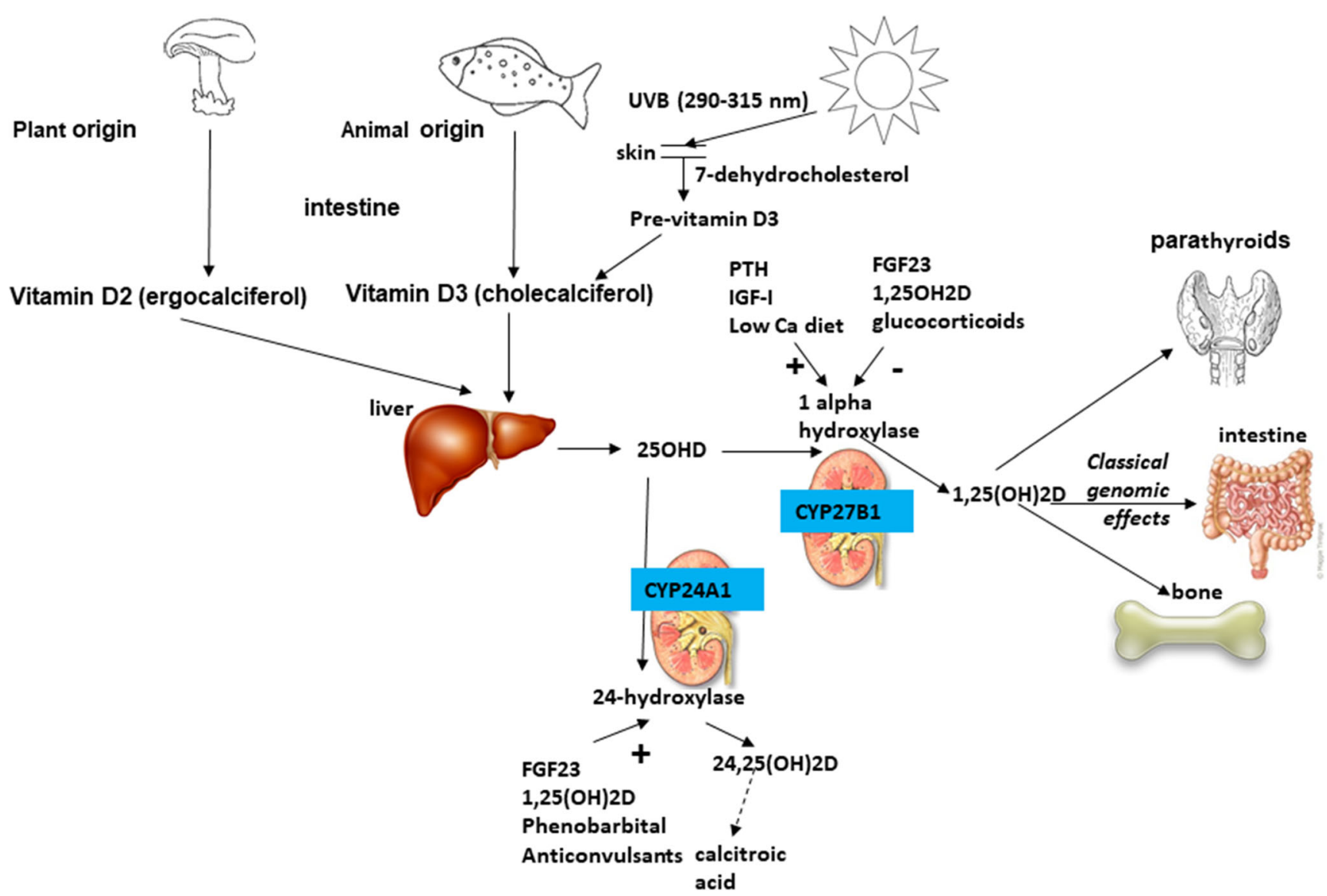

Fig. 1 Vitamin D metabolism

\section{Assays variability for vitamin D status assessment}

Measurement of serum circulating 25(OH)D level to evaluate vitamin D status in patients who are at risk of vitamin D deficiency should be performed using a reliable and standardized assay. Substantial variability in $25(\mathrm{OH}) \mathrm{D}$ measurement exists between the different assays available, whatever the methodology used [21]. Without standardization, the bias observed between the methods renders impossible the integration of the different studies in meta-analyses allowing valid recommendations. In this context, the vitamin D standardization program (VDSP) developed a reference measurement system including gold standard reference method procedures (RMPs from NIST, CDC, and the University of Ghent), NIST Standard Reference Materials, and a Standardization Certification Program (VDSCP) aiming at standardization of $25(\mathrm{OH}) \mathrm{D}$ measurement [22]. Its objective is that laboratories using standardized $25(\mathrm{OH}) \mathrm{D}$ assays report not only the same value but most importantly the true $25(\mathrm{OH}) \mathrm{D}$ concentration. The list of the certified assays is hosted on the CDC website (https://www.cdc.gov/labstandards/pdf/hs/CDC_Certified Vitamin_D_Assays-508.pdf). Serum total $25(\mathrm{OH}) \mathrm{D}$ is expressed by the sum of the serum concentrations of $25(\mathrm{OH})$ $\mathrm{D} 2$ and $25(\mathrm{OH}) \mathrm{D} 3$. However, 25-OHD2 is not equivalently recognized by all immunoassays [23], and standardization of 25-OHD2 is not achieved yet. In countries where vitamin D2 can be used as a pharmaceutical supplement, LCMS/MS methods or methods equivalently recognizing both moieties should be preferred.

\section{Other vitamin D metabolites as markers of vitamin status?}

1,25- $(\mathrm{OH})_{2} \mathrm{D}$ measurement should not be used to evaluate vitamin $\mathrm{D}$ status due to its tight regulation and its short halflife. Indeed, serum $1,25-(\mathrm{OH})_{2} \mathrm{D}$ levels in vitamin $\mathrm{D}$ deficient individuals are often normal and may even be elevated due to secondary hyperparathyroidism. However, 1,25- $(\mathrm{OH})_{2} \mathrm{D}$ may be useful in some specific situations, for example, exploration of non-PTH-mediated hypercalcemia, vitamin D-dependent rickets, tumor-induced osteomalacia, and hypophosphatemic rickets.

Free $25(\mathrm{OH}) \mathrm{D}$, bound to neither vitamin $\mathrm{D}$ binding protein (VDBP) nor albumin, can be calculated using a formula that takes into account 25(OH)D, VDBP, and albumin [24, 25] or with an ELISA kit (Diasource, Belgium). The choice of assay for VDBP in the calculation of free $25(\mathrm{OH}) \mathrm{D}$ is of importance to correctly capture the VDBP polymorphism variants which are present in white and black individuals [26, 27]. 
Nevertheless, the very low concentration of free and bioavailable $25(\mathrm{OH}) \mathrm{D}$ as well as the lack of a reference method remain clear limitations and support the measurement of total $25(\mathrm{OH}) \mathrm{D}$ in the general population as a marker of vitamin $\mathrm{D}$ status.

\section{$24,25(\mathrm{OH})_{2} \mathrm{D}$ to replace $25(\mathrm{OH}) \mathrm{D}$ as a marker of vitamin $\mathrm{D}$ deficiency?}

Both concentrations of $25(\mathrm{OH}) \mathrm{D}$ and $24,25-(\mathrm{OH})_{2} \mathrm{D}$ are strongly correlated. Indeed vitamin D catabolism is predominantly due to CYP24A1 which through 24-hydroxylase (stimulated by FGF23, 1,25- $(\mathrm{OH})_{2} \mathrm{D}$, phenobarbital and anticonvulsants) metabolizes $1,25-(\mathrm{OH})_{2} \mathrm{D}$ to $1,24,25-(\mathrm{OH})_{3} \mathrm{D}$ and $25(\mathrm{OH}) \mathrm{D}$ to $24,25-(\mathrm{OH})_{2} \mathrm{D}$ (Fig. 1). Therefore, serum $24,25(\mathrm{OH})_{2} \mathrm{D}$ concentration depends on the availability of $25(\mathrm{OH}) \mathrm{D}$ and the expression of CYP24A1 which is in part regulated by VDR and then $24,25(\mathrm{OH})_{2} \mathrm{D}$ reflects VDR activity. It also means that when sufficient amounts of biologically active vitamin D are available, CYP24A1 is upregulated, and more $24,25(\mathrm{OH})_{2} \mathrm{D}$ is formed $[28,29]$. This approach could lead to a better personalization of vitamin $\mathrm{D}$ supplementation [30]. Nevertheless, measurement of $24,25(\mathrm{OH})_{2} \mathrm{D}$ and VMR (vitamin D metabolite ratio of serum, $24,25(\mathrm{OH})_{2} \mathrm{D}$ to $25(\mathrm{OH}) \mathrm{D})$ values are available only to clinical laboratories equipped with LC-MS capabilities in the absence of available automated immunoassays.

In summary, vitamin D status can be assessed by measuring serum $25(\mathrm{OH}) D$ level with a robust and reliable standardized assay. The other vitamin $D$ metabolites $1,25-(\mathrm{OH})_{2} \mathrm{D}$, free $25(\mathrm{OH}) \mathrm{D}$, and even $24,25(\mathrm{OH})_{2} \mathrm{D}$ should not be used as a surrogate marker of vitamin $D$ status.

\section{Prevalence of vitamin D insufficiency/deficiency in patients admitted to the orthopedic ward}

\section{Interpretation of serum levels of 25(OH)D OHD}

Vitamin D deficiency is a potential problem for countries at high latitude and can ranged between 10 and $40 \%$ in winter according mainly to regional sunlight exposure and to a lesser degree to dietary vitamin D intake [31-33]. Serum 25(OH)D status varies also according to gender and age as reported among 95,000 Korean men and women [32]. The mean $25(\mathrm{OH}) \mathrm{D}$ levels were higher in men than in women for all age groups and were highest in those aged $\geq 70$ years and lowest in younger individuals $<30$ years in both genders.

Body composition can influence serum levels of $25(\mathrm{OH}) \mathrm{D}$ as shown in an elderly cohort of German women in which $25(\mathrm{OH}) \mathrm{D}$ levels were affected by total body fat after controlling for age, lifestyle, and serum intact PTH [34]. In a meta-analysis of 21 studies including up to $42^{\prime} 024$ subjects, each unit $\left(\mathrm{kg} / \mathrm{m}^{2}\right)$ increase in BMI was associated with $1.15 \%$ lower concentrations of $25(\mathrm{OH}) \mathrm{D}$ after adjusting for age, sex, laboratory batch, and month of measurement [35]. BMI and BMI single-nucleotide polymorphisms (SNPs) were associated with $25(\mathrm{OH}) \mathrm{D}$, while $25(\mathrm{OH}) \mathrm{D}$ SNPs were not associated with BMI. This study, on the basis of a bi-directional genetic approach, suggested that a higher BMI leads to lower $25(\mathrm{OH}) \mathrm{D}$, while any effects of lower 25(OH)D increasing BMI were likely to be small.

Acute infection may alter vitamin D status. To characterize this deleterious effect of acute infection on vitamin D status, 6 vitamin-replete bull calves were experimentally infected with bovine viral diarrhea virus and compared to 6 sham-inoculated controls [36]. During the last 8 days of the 14-day post-inoculation period, serum 25(OH)D concentrations decreased by $51 \%$ in infected calves, and the inverse association between vitamin $\mathrm{D}$ status and serum amyloid A suggested that the infection-induced acute phase response contributed to the reduced serum 25(OH)D concentration. Furthermore, during a systemic inflammatory response induced $48 \mathrm{~h}$ after elective orthopedic surgery in 30 patients, serum $25(\mathrm{OH}) \mathrm{D}$ concentrations as well as VDBP decreased suggesting that serum $25(\mathrm{OH}) \mathrm{D}$ as a biomarker of vitamin D status should be interpreted with caution in the context of acute inflammation [37].

\section{Prevalence of vitamin D deficiency in patients with osteoporotic fractures}

Among patients with osteoporotic fractures, prevalence of vitamin D deficiency is high. Risk factors for vitamin D deficiency include a lack of sun exposure, dark skin, low intake, liver and gastrointestinal diseases, and some drugs. In a prospective study including Japanese postmenopausal women with osteoporotic fractures and a mean age of 80.7 years, $78 \%$ of these patients had $25(\mathrm{OH}) \mathrm{D}$ concentrations $<50$ $\mathrm{nmol} / \mathrm{l}(20 \mathrm{ng} / \mathrm{ml})$ with lower values in hip fractures than in vertebral or distal radius fractures [38] (Fig. 2). As compared, higher 25(OH)D levels were observed in Japanese postmenopausal women without fracture [39] (Fig. 2). Many studies in patients with hip fractures and an average age of around 80 years and over have reported a prevalence of serum $25(\mathrm{OH}) \mathrm{D}$ below $50 \mathrm{nmol} / 1$ ranging between 34 and $80 \%$, even if mean values are around 40 to $50 \mathrm{nmol} / 1[12,14,40-48]$ (Table 1 ). A high prevalence of vitamin D deficiency was also observed among 219 orthopedic patients presenting with vertebral fragility fractures [49] as well as among 93 patients with pelvic insufficiency fractures [50]. Vitamin D insufficiency or deficiency was also common across all age groups in two cohorts of patients undergoing fracture repair surgery [51]. In a metaanalysis exploring the correlation between serum 25(OH)D 
Table 1 Circulating calcifediol levels in patients admitted to orthopedic wards for fragility fractures

\begin{tabular}{llllll}
\hline Study & Country & Population (\% female) & Mean (SD) age, years & Mean (SD) 25(OH)D nmol/1 & $\%$ 25(OH)D < 50 nmol/1 \\
\hline Awal et al. [40] & Australia & 313 & 79.5 & & 34 \\
Hao et al. [14] & USA & $290(73)$ & $82(7)$ & $55(24)$ & 46 \\
Bischoff-Ferrari et al. [12] & Switzerland & $222(77)$ & 86 & 34.6 (community) & 80 \\
Cher et al. [41] & Singapore & $801(71)$ & $77.7(8)$ & - & 47.4 \\
Niikura et al. [44] & Japan & $360878)$ & $84.7(8.2)$ & $41.3(18)$ & 71.7 \\
Papaiannou et al. [45] & Canada & $65(56)$ & $78.5(10.3)$ & 52.3 & - \\
Ish-Shalom et al. [46] & Israel & $48(100)$ & $81(89$ & $39.3(25.3)$ & - \\
Mak et al. [47] & Australia & $218(77)$ & $83.9(7.2)$ & $52.7(23.5)$ & 47 \\
Moo et al. [48] & Singapore & $796(71)$ & $77.7(8)$ & $50.1(18.5)$ & 53.9 \\
\hline
\end{tabular}

\# Proximal femur fracture ; ${ }^{*}$ Hip fracture

levels and osteoporotic fractures in elderly, high as compared to low serum $25(\mathrm{OH}) \mathrm{D}$ levels were associated with reduced risk of hip fracture but had no significant relationship with total fracture risk [52]. Vitamin D deficiency may contribute to the pathogenesis of fragility fracture through altered bone strength and increasing fall risk and indeed may also be relevant for post-fracture recovery (Fig. 3). Indeed, in a recent study among 290 hip fracture patients, those with a vitamin D deficiency $(25(\mathrm{OH}) \mathrm{D}<25 \mathrm{nmol} / \mathrm{l} ; 12 \%)$ had a reduced mobility at 60 days after the fracture [14]. In another study in Singapore among 801 hip fracture patients, $25(\mathrm{OH}) \mathrm{D}$ insufficiency and/or deficiency affecting about $92 \%$ of patients was a significant predictor of mortality at 2 years but not at 90 days [41]. Despite severe vitamin D deficiency below 30 $\mathrm{nmol} / \mathrm{l}$ being present in the majority of hip fracture patient, only $10 \%$ of hip fracture patients had any vitamin D supplementation on admission [12]. The prevalence of vitamin D deficiency is even higher in patients with previous contralateral hip fractures as compared to those without [44], suggesting that most surgeons do not prescribe vitamin $\mathrm{D}$ to fractured patients. Patients with osteoporotic fractures and/or musculoskeletal symptoms, which can be potentially improved by vitamin D treatment or need the correction of vitamin D deficiency prior to specific treatment, should have serum 25(OH)D levels measured [53]. Since there is no daily circadian rhythm, fasting is not needed, and samples should be taken before the next load when monitoring weekly or monthly doses.

In summary, there is a high prevalence of vitamin D insufficiency or deficiency in patients with fragility fractures and especially in those with a hip fracture. Determinants of $25(\mathrm{OH}) D$ concentrations include the seasonality and latitude as well as some conditions such as obesity, malnutrition, acute inflammation, or infection which can lower serum vitamin D levels.

\section{Role of vitamin $D$ in fracture healing and material osseointegration}

Vitamin D deficiency can adversely affect fracture healing and conceivably contribute to the development of nonunion [54]. It may account for the concomitant findings of elevated alkaline phosphatase, elevated parathyroid hormone, and low calcium levels observed in some patients [55]. In a casecontrol study, the prevalence of 25(OH)D levels below 23 $\mathrm{nmol} / \mathrm{l}$ was $60 \%$ in a group of non-union closed tibia fracture, while it was $30 \%$ only in those with union by 3 to 6 months of follow-up [56]. In a large database with more than 300,000 fractures, vitamin D deficiency was associated with an odds ratio of 1.14 of non-union, which affected $4.9 \%$ of the fractures [57]. As mechanism for non-union, impaired IL-4 and IL-13 production under vitamin D deficiency has been proposed, since these cytokines increase bone formation and fracture bridging [58].

However, a high-dose bolus of vitamin $\mathrm{D}_{3}$ during the acute recovery period did not impact the rate of union in vitamin $\mathrm{D}$ deficient patients with a long bone fracture in a randomized double-blind placebo-controlled trial [59]. Out of 2 trials having tested the effects on fracture healing of proximal humerus [60] or upper and lower limbs fractures [61] of 800 and 1200 IU vitamin $\mathrm{D}$ per day, respectively, the former concluded to some improved fracture healing by higher bone content in the callus with vitamin D. In the latter, the incidence of delayed union was $9.7 \%$ in the group who remained vitamin D deficient, while it was $0.3 \%$ in the vitamin D replete at baseline and $1.7 \%$ in those the deficiency of whom was corrected. In both trials, $1 \mathrm{~g}$ calcium supplements were administered as well. The contrasting effects of vitamin D supplementation on fracture healing have been reviewed elsewhere [62, 63].

A few preclinical studies reviewed in $[64,65]$ have concluded to a lower bone to implant contact and impaired 
Fig. 2 Calcifediol (25-OHD) levels by fracture type from Fig. 1 [38] and in postmenopausal women without fracture (adapted from Fig. 1) [39]. Calcifediol levels in 317 fractured women with a mean age of 81 years. Values below $50 \mathrm{nmol} / 1(20$ $\mathrm{ng} / \mathrm{ml}$ ) were found in $78 \%$ [38]
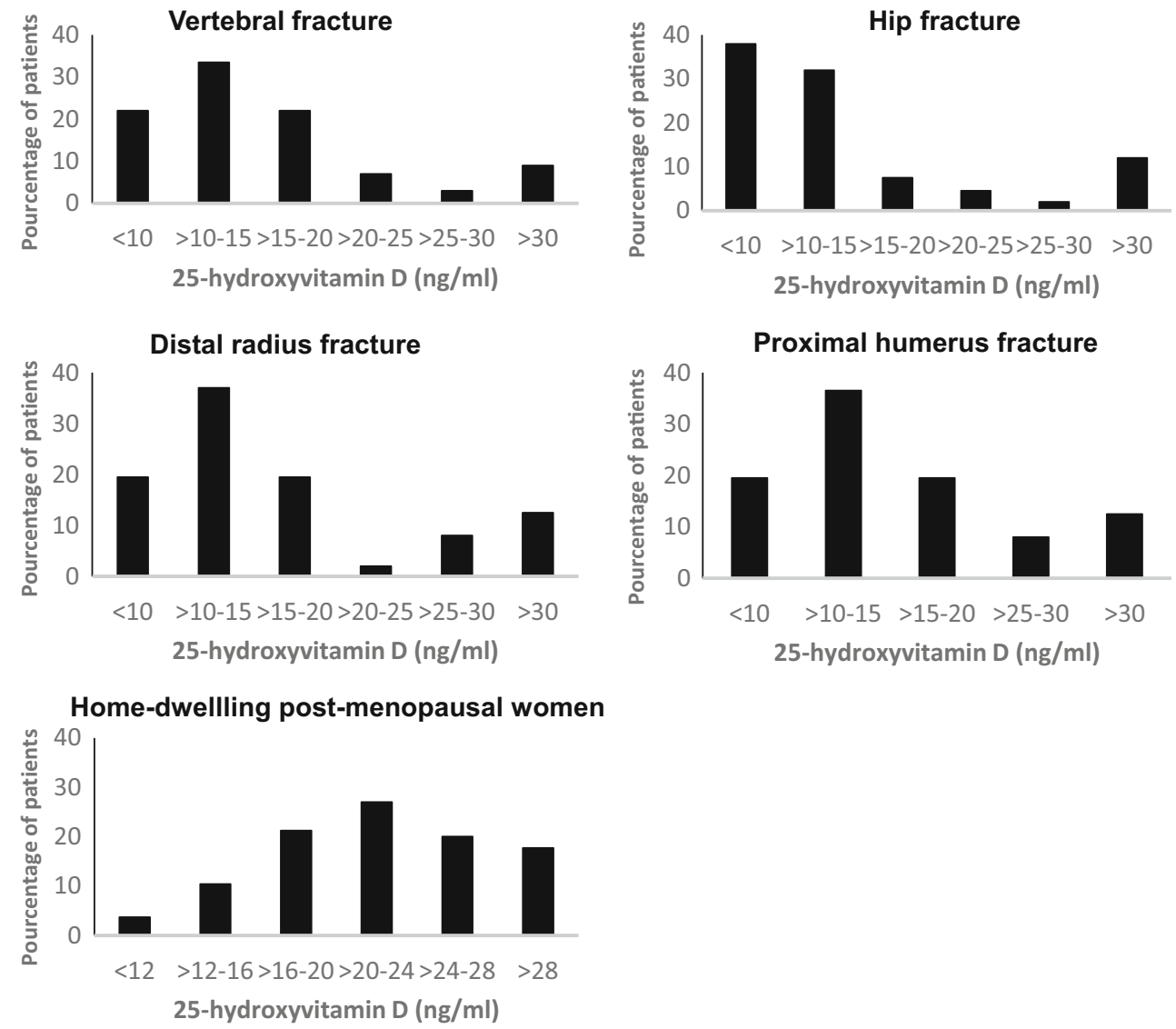

functional osseointegration in vitamin deficient animals. There seems to be a clear association between hypovitaminosis D and an impaired osseointegration, with a higher probability of early implant failure, as reported in both clinical studies and animal models $[66,67]$. It seems that bone healing process and bone metabolism are strongly influenced by nutritional aspects and are essential to reach a good bone restoration, enhancing the osseointegration processes. These effects were sustained by vitamin D administration. Both in
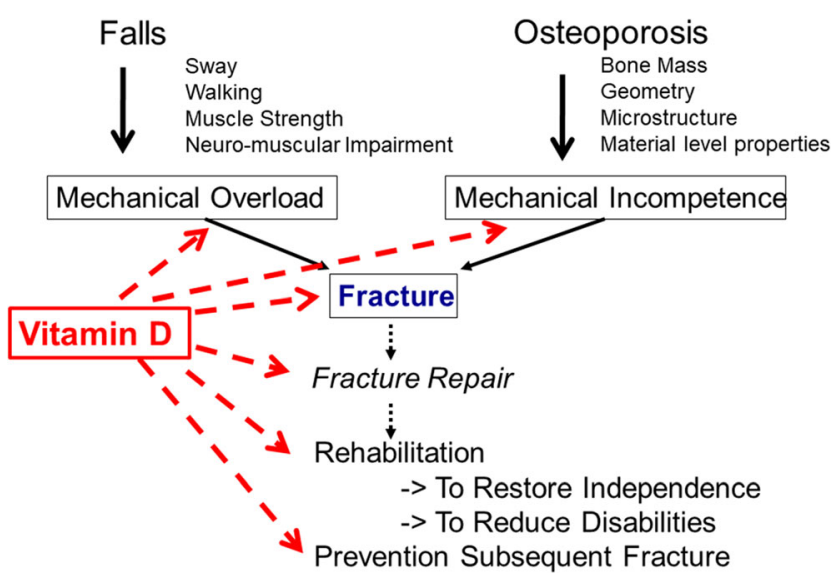

Fig. 3 Role of vitamin D in the pathogenesis and management of osteoporotic fractures (adapted from [7]) the frail elderly and in younger patients, with a traumatic fracture, hypovitaminosis $\mathrm{D}$ is associated with a worse bone stock and a delay in the formation of callus and healing [68]. Vitamin D promotes mineralization and bone repair processes [69]. In patients who undergo hip and knee prostheses, hypovitaminosis $\mathrm{D}$, favored by the inflammatory reaction, can compromise surgical outcome and functional recovery [70]. In these patients, vitamin D supplementation may be useful to ensure proper osseointegration and, therefore, a better surgical outcome [71]. Low vitamin D levels are also associated with increased exposure to infections [72, 73], a longer length of hospital stay [74], and a higher frequency of post-operative complications. In these patients, supplementation should be considered. Retrospective clinical studies would suggest some trend to early dental implant failure in patients with low circulating 25-OHD [75, 76]. Intervention trials with vitamin D are still missing.

The effects of vitamin D deficiency and/or vitamin D supplementation on fracture healing in clinical studies are rare. However, the overall impression is that vitamin D has a positive influence on this process, but the mechanism and the magnitude of the effect remain to be determined. The role of vitamin $D$ in material osseointegration requires further investigation. 


\section{Rehabilitation after osteoporotic fracture}

\section{Multidimensional approach of rehabilitation}

The main goals of fracture management are to recover prefracture functional level and to reduce fracture risk (Fig. 3). Rehabilitation of the patient with fragility fracture begins in acute settings within $24 \mathrm{~h}$ (possibly within a few hours) after surgery or any conservative treatment [77]. Rehabilitation program of hip fractures include multimodal pain management, intensive post-discharge physical therapy, and an interdisciplinary care program even in patients with mild to moderate dementia to improve functional outcomes [78]. Moderate evidence supports that postoperative nutritional supplementation improves nutritional status and reduces mortality and that supervised occupational and physical therapy across the continuum of care, including home, improves functional outcomes and fall prevention [78]. Some influence on length of stay in rehabilitation ward has been suggested with dietary protein repletion [79]. Complex, multidimensional, mHealth interventions hold promise to health behavior change related to calcium and vitamin D intake, balance, core and leg strength, and physical activity [80].

\section{Care pathway of patient with hip fracture}

For patients with hip fracture, an early admission could improve care by an orthopedist and a geriatrician team during both the acute and rehabilitation phases [81], in combination with a physiatrist $[82,83]$. Indeed, a recent meta-analysis showed a decrease of, respectively, 27 and 19\%, in 30-day and 1-year mortality after initiating an orthogeriatric program in patients with recent hip fractures [84]. In addition, a decrease in complications such as confusion states, urinary tract infections, pressure ulcers, cardiac decompensations, and thromboembolic events was observed in patients with recent hip fracture who underwent a joint orthogeriatric management either in retrospective studies [85], before/after implementation [86], or in a meta-analysis [87]. Functionality in the first 3 months after a hip fracture was also significantly improved thanks to orthogeriatric co-management in three studies including two randomized studies [88-90]. In another recent randomized study in non-institutionalized patients aged 70 years and over and able to walk at least $10 \mathrm{~m}$ before their hip fracture, the SPPB (short physical performance battery) score, as well as the Barthel index were better in patients of the co-management group not only during the first weeks but also at 4 and 12 months [91].

\section{Vitamin D and the musculoskeletal system}

Vitamin D plays an important role in orthopedic surgery [92]. Low vitamin D levels in patients undergoing total hip replacement have been associated with lower pre- and postoperative Harris hip score [93], increase of postoperative complications, including periprosthetic joint infection [72] as well as longer hospital stays [74]. Severe vitamin D deficiency is causing muscle pain and weakness as well as gait impairment [16]. In a cross-sectional study in adults, serum 25(OH)D level on admission to acute rehabilitation unit was inversely associated with non-specific musculoskeletal pain [94]. Vitamin D deficiency has been associated with proximal muscle weakness, increase in body sway, and an increased risk of falling $[9,95,96]$. In a prospective observational study in inpatients with hip fractures, $25(\mathrm{OH}) \mathrm{D}_{3}$ below $30 \mathrm{nmol} / \mathrm{l}(12$ $\mathrm{ng} / \mathrm{ml}$ ) was associated with worse functional recovery (Barthel index) than those between 30 and $50 \mathrm{nmol} / \mathrm{l}$ (12-20 $\mathrm{ng} / \mathrm{ml}$ ) that were in turn associated with a worse recovery than those between 50 and $75 \mathrm{nmol} / \mathrm{l}(20-29 \mathrm{ng} / \mathrm{ml})$, but with no further advantages with serum 25(OH)D above $75 \mathrm{nmol} / 1$ (30 $\mathrm{ng} / \mathrm{ml}$ ) [97]. Vitamin D sufficiency may play an important role in lower extremity function 1 year after hip fractures [98]. In a meta-analysis of 11 observational studies bringing together 39,141 participants, an increase in serum $25(\mathrm{OH}) \mathrm{D}$ of 10 $\mathrm{ng} / \mathrm{ml}(25 \mathrm{nmol} / \mathrm{l})$ was associated with a risk reduction of $20 \%$ for hip fractures and of $7 \%$ for any fracture [99].

\section{Vitamin D supplementation}

ESCEO recommends a $50 \mathrm{nmol} / \mathrm{L}$ (i.e., $20 \mathrm{ng} / \mathrm{mL}$ ) as the minimal serum $25(\mathrm{OH}) \mathrm{D}$ concentration at the population level and $75 \mathrm{nmol} / \mathrm{l}$ in patients with osteoporosis to ensure optimal bone health [7]. For vitamin D supplementation, ESCEO maintains its recommendation at a dosage of $800 \mathrm{IU} /$ day [100] which is in line with the majority of current vitamin D recommendations in Europe for women older than 50 years [100-105], as well as those of the Institute of Medicine (IOM)/Endocrine Society [106, 107] and International Osteoporosis Foundation (IOF) [108] (Table 2). Patients with symptomatic deficiency or those requiring treatment prior to receiving a potent antiresorptive agent may receive beforehand a single loading dose of $300,000 \mathrm{IU}$ or $50,000 \mathrm{IU} /$ week over 6 weeks, followed by maintenance doses of 800 1000 UI daily to maintain appropriate vitamin D levels [53, 109]. When vitamin $D$ is co-prescribed with an oral antiresorptive agent, the maintenance dose of 800-1000 IU can be started [53] but may increase to 2000 IU/day in conditions of severe vitamin D deficiency, renal failure, or obesity [110]. In case of important comorbidities, a consultation with a metabolic bone disease specialist may be indicated. On the other hand, in patients with baseline serum $25(\mathrm{OH}) \mathrm{D}$ around $50 \mathrm{nmol} / \mathrm{l}$, a randomized study after acute hip fracture has shown no advantage of loading doses over daily supplementation to reach a target therapeutic threshold of $75 \mathrm{nmol} / \mathrm{l}$ [45]. Oral cholecalciferol (D3) is generally the recommended form [111]. If only one loading dose is considered, no more than 
Table 2 Recommended vitamin D supply in women older than 50 years

Authority and/or country (year) Recommended intake of vitamin D (IU/d)

\begin{tabular}{llll} 
& Age 50-60 years & Age 61-70 years & Age > 70 years \\
\hline IOF (2010) [108] & 800 & 800 & $800-1000$; up to 2000 IU/day if needed to achieve sufficient vitamin D level \\
IOM (2011) [106] & 600 & 600 & 800 \\
Endocrine society (2011) [107] & 600 & 600 & $800 ;$ up to 1500-2000 IU/day if needed to achieve sufficient vitamin D level \\
DACH (2012) [101] & 800 & 800 & 800 \\
Nordic countries (2012) [102] & 400 & 400 & 800 (>75 years) \\
ESCEO (2013) [100] & 800 & 800 & 800 \\
EFSA (2016) [103] & 600 & 600 & 600 \\
UK (SACN 2016) [104] & 400 & 400 & 400 \\
ESCEO-IOF (2019) [105] & 800 & 800 & 800
\end{tabular}

IOF (International Osteoporosis Foundation); IOM (Institute of Medicine) ; DACH (Germany (D), Austria (A) and Switzerland (CH)); ESCEO (European Society for Clinical and Economic Aspects of Osteoporosis, Osteoarthritis and Musculoskeletal Diseases); EFSA (European Food Safety Authority); UK SACN (United Kingdom-Scientific Advisory Committee on Nutrition)

100 '000 IU should be prescribed since a higher rate of falls and fractures has been described in several studies using higher doses in older participants [112-115]. A systematic review has evaluated the effectiveness of combined exercise training and vitamin D supplementation on musculoskeletal health in older adults and has concluded to an additive effect of resistance exercise and vitamin D supplementation on muscle strength [116]. However, no additional benefit beyond exercise was shown for other functional variables such as short physical performance battery and the timed up and go test.

Adequate vitamin D status is necessary for the functional recovery process. For patients with hip fracture, a comanagement by an orthopedist and a geriatrician has demonstrated significant benefits by decreasing medical complications and mortality and improving functional independence.

\section{Fracture liaison service: a need for an optimal management of the vitamin $D$ deficiency in patients with fragility fracture}

\section{Fracture liaison service (FLS)}

Fracture liaison service started in the late 1990s to address the growing problem of bone fragility [117]. Indeed, following fragility fractures, there is at least a twofold risk of refracture $[118,119]$, and this risk can even be multiplied by 4 times after initial vertebral fracture [120]. Furthermore, the risk of major osteoporotic fracture (MOF) after a first MOF is increased over the whole duration of follow-up, but the imminent risk for the first 2 years is even higher justifying the rapid introduction of antiosteoporosis treatment after a fracture [121]. Unfortunately, in many instances, diagnosis, evaluation, and treatment of osteoporosis, including correction of vitamin D deficiency, are not undertaken after a fragility fracture [122-127]. Orthopedic surgeons are well aware of a care gap for patients presenting with a fragility fracture. Indeed, in two surveys, the majority of orthopedic surgeons would prefer to establish a fracture liaison service rather than to pursue a protocol-based approach to address the osteoporosis care gap at their institutions [128]. The goal of an FLS is to ensure a management continuity in patients who sustained a fragility fracture from the time of injury presentation until the transition to the primary care provider through an interdisciplinary team [117, 129-131] [132]. The essential elements of an FLS include identification and assessment of patients with fragility fracture, exercise, and education programs including dietary counselling, falls risk assessment, initiation of osteoporosis medication including vitamin $\mathrm{D}$ repletion, and long-term follow-up and/or transition of care through a comprehensive management plan to primary care provider and a fully integrated FLS database system [129]. FLS reduce not only the incidence of subsequent fractures by around 30\% [86, 133-136] by improving prescription [137] and adherence to prevention protocols and antiosteoporosis medication [138]. FLS are cost saving [139-141]. Therefore, secondary prevention of fractures with FLS is now considered as a standard of care with the worldwide implementation of FLS [142-144]. Since its launch in 2013, Capture the Fracture®, a global program of IOF, has welcomed a growing number of FLS and continues to facilitate the implementation of FLS worldwide. Until September 2020, this network of FLS has reached 440 from 48 countries, spread across 6 continents.

\section{Impact of FLS on prescription}

Drug therapy is an essential component of management of patients with fragility fracture and cannot be limited to vitamin $\mathrm{D}$ and calcium supplementation [145]. In a cohort of 3475 
osteoporotic patients with a recent vertebral or hip fracture, the risk of re-fracture after a mean follow-up of 3 years was $44.4 \%$ lower in patients under anti-osteoporotic treatment compared to untreated ones [146]. This risk of subsequent fracture was $64.4 \%$ lower in those receiving calcium/vitamin D supplementation in addition to osteoporosis treatment and $77.2 \%$ lower in patients who were adherent to medication. Over this follow-up period, a $64 \%$ lower mortality risk was also observed [146]. In another study among patients aged over 85 years with a clinical fracture, a significant lower cumulative mortality was observed over 2 years in the FLS attenders group without a reduced subsequent fracture rate [147].

A spectacular improvement in vitamin D status in elderly women with a fragility fracture has been observed over an 8 year analysis in a dedicated FLS in France since the level of patients with severe hypovitaminosis D fell dramatically from 79.3 to $19.7 \%$, showing that supplementation has been widely integrated into current practice [148]. In a secondary FLS analysis in Taiwan on participants grouped according to fracture types, there were significant differences after intervention between baseline and 12-month in calcium/vitamin D supplementation use, adequate protein intake, and exercise rate (except for hip fracture group) [149]. Post-hip fracture use of calcium and vitamin $\mathrm{D}$ was shown to be a protective factor on mortality over a minimum of 11-year follow-up in a study performed in Finland [150]. In another small FLS cohort of hip fracture patients in the USA, a higher proportion of patients changed vitamin D intake after the FLS program was instituted and a higher proportion obtained a BMD measurement, but there was no increase in the proportion of patients taking osteoporosis medication [151]. On the other hand, another FLS in the USA increased the percentage of patients under osteoporosis medication from 20 to $54 \%$ as well as calcium/vitamin D prescription from $36 \%$ at baseline to $93 \%$ and the percentage of patients receiving BMD testing from 21 to $93 \%$ [152]. Higher prescription of osteoporosis medication is of importance since a $40 \%$ lower subsequent fracture risk and $21 \%$ lower mortality risk were observed in a prospective FLS cohort study in Glasgow in which $50.7 \%$ of patients were recommended for oral bisphosphonates [153]. Since FLS may be less feasible and accessible in rural areas, with limited availability of care services, a centralized E-consult program can effectively and efficiently provide specialty bone health services to patients with recent fracture residing in rural areas [154]. Since the COVID-19 pandemic is also influencing healthcare delivery for osteoporosis outpatients, remote consultations are also applicable to osteoporosis services [155].

The FLS model can help to inform orthopedic surgeons on the importance of vitamin D status in the management of patients with fragility fractures in addition to antiosteoporotic treatment. Therefore, vitamin D status should be included in Capture the Fracture ${ }^{\circledR}$ program as an outcome of FLS in addition to DXA and specific anti-osteoporotic medication. However, long-term studies on the impact of FLS on major outcomes are still to be investigated.

\section{Conclusions}

- There is a high prevalence of vitamin D insufficiency and/ or deficiency in patients with fragility fractures and especially in those with a hip fracture.

- Vitamin D status can be assessed by measuring serum 25(OH)-vitamin D level with standardized assays.

- Vitamin D may have a positive influence on fracture healing, but the mechanism and the magnitude of the effect remain to be determined.

- Adequate vitamin D status which plays an important role in the musculoskeletal system is required for the functional recovery after fracture.

- For vitamin D supplementation, a dosage of 800-1000 IU/ day is in line with the majority of current vitamin $\mathrm{D}$ recommendations in Europe for women older than 50 years.

- In patients with fragility fracture, a serum $25(\mathrm{OH}) \mathrm{D}$ concentration of $75 \mathrm{nmol} / 1(30 \mathrm{ng} / \mathrm{ml})$ should be targeted to ensure optimal musculoskeletal health.

- The FLS model can help to inform orthopedic surgeons and their patients on the importance of vitamin D status in the management of patients with fragility fractures in addition to anti-osteoporotic treatment.

\section{Research agenda}

- To further clarify the role of vitamin D levels and supplementation in fracture healing and material osseointegration

- To evaluate the role of a vitamin D loading dose and its regimen on clinical relevant outcomes

- To evaluate whether vitamin $\mathrm{D}$ dose should be adapted to the level of renal function

- To test the effects of combined vitamin D and calcium on imminent fracture risk

Funding Open access funding provided by University of Geneva. MLB has received consultancy, lecture fees, and honoraria from Abiogen, Alexion, Amgen, Bruno Farmaceutici, Kyowa Kirin, Servier, and SPA. EC is consultant for DiaSorin, Fujirebio, IDS, Menarini, Nittobo and bioMérieux. NCH has received consultancy, lecture fees, and honoraria from Alliance for Better Bone Health, AMGEN, MSD, Eli Lilly, Servier, UCS, Shire, Consilient Healthcare, Kyowa Kirin and Internis Pharma. $\mathrm{CC}$ has received consultancy, lecture fees, and honoraria from AMGEN, GSK, Alliance for Better Bone Health, MSD, Eli Lilly, Pfizer, Novartis, Servier, Medtronic and Roche. SM reports grants from SANOFI, MSD, GSK, PFIZER, TAKEDA, MYLAN through institution as organizer of meetings/congresses and as principal investigator of 
epidemiological studies, for taking part to advisory boards and expert meetings. NS has received fees for lectures or scientific advisory boards from AgNovos, EliLilly, Amgen, AO Foundation, UCB Pharma, Roche, Labatec. JYR reports consulting fees or advisory board participation for IBSA-Genevrier, Mylan, Radius Health and Pierre Fabre, lecturing fees for IBSA-Genevrier, Mylan, Cniel and Dairy Research Council (DRC) and grant support from IBSA-Genevrier, Mylan, Cniel and Radius Health. RR has received fees for lectures or scientific advisory boards from Abiogen, Danone, Echolight, European Milk Forum, Mithra, ObsEva, Pfizer Consumer Health and Theramex. The Working Group was entirely funded by the ESCEO. The ESCEO receives Unrestricted Educational Grants, to support its educational and scientific activities, from non-governmental organizations, not-for-profit organizations, noncommercial and corporate partners. The choice of topics, participants, content and agenda of the Working Groups, as well as the writing, editing, submission and reviewing of the manuscript are under the sole responsibility of the ESCEO, without any influence from third parties.

\section{Declarations}

\section{Conflict of interest None.}

Open Access This article is licensed under a Creative Commons Attribution-NonCommercial 4.0 International License, which permits any non-commercial use, sharing, adaptation, distribution and reproduction in any medium or format, as long as you give appropriate credit to the original author(s) and the source, provide a link to the Creative Commons licence, and indicate if changes were made. The images or other third party material in this article are included in the article's Creative Commons licence, unless indicated otherwise in a credit line to the material. If material is not included in the article's Creative Commons licence and your intended use is not permitted by statutory regulation or exceeds the permitted use, you will need to obtain permission directly from the copyright holder. To view a copy of this licence, visit http:// creativecommons.org/licenses/by-nc/4.0\%.

\section{References}

1. Schurch MA, Rizzoli R, Mermillod B, Vasey H, Michel JP, Bonjour JP (1996) A prospective study on socioeconomic aspects of fracture of the proximal femur. J Bone Miner Res 11:19351942

2. Johnell O, Kanis JA (2004) An estimate of the worldwide prevalence, mortality and disability associated with hip fracture. Osteoporos Int 15:897-902

3. Piscitelli P, Neglia C, Feola M, Rizzo E, Argentiero A, Ascolese M, Rivezzi M, Rao C, Miani A, Distante A, Esposito S, Iolascon G, Tarantino U (2020) Updated incidence and costs of hip fractures in elderly Italian population. Aging Clin Exp Res 32:25872593

4. Pedersen AB, Ehrenstein V, Szepligeti SK, Lunde A, Lagerros YT, Westerlund A, Tell GS, Sorensen HT (2017) Thirty-fiveyear trends in first-time hospitalization for hip fracture, 1-year mortality, and the prognostic impact of comorbidity: a Danish nationwide cohort study, 1980-2014. Epidemiology 28:898-905

5. Borgstrom F, Karlsson L, Ortsater G et al (2020) Fragility fractures in Europe: burden, management and opportunities. Arch Osteoporos 15:59

6. Roth DE, Abrams SA, Aloia J, Bergeron G, Bourassa MW, Brown KH, Calvo MS, Cashman KD, Combs G, de-Regil LM, Jefferds ME, Jones KS, Kapner H, Martineau AR, Neufeld LM, Schleicher RL, Thacher TD, Whiting SJ (2018) Global prevalence and disease burden of vitamin D deficiency: a roadmap for action in low- and middle-income countries. Ann N Y Acad Sci 1430: 44-79

7. Rizzoli R (2014) Nutritional aspects of bone health. Best Pract Res Clin Endocrinol Metab 28:795-808

8. Bouillon R, Carmeliet G (2018) Vitamin D insufficiency: definition, diagnosis and management. Best Pract Res Clin Endocrinol Metab 32:669-684

9. Bischoff-Ferrari HA, Dietrich T, Orav EJ, Hu FB, Zhang Y, Karlson EW, Dawson-Hughes B (2004) Higher 25hydroxyvitamin D concentrations are associated with better lower-extremity function in both active and inactive persons aged $>$ or $=60 \mathrm{y}$. Am J Clin Nutr 80:752-758

10. Wicherts IS, van Schoor NM, Boeke AJ, Visser M, Deeg DJ, Smit J, Knol DL, Lips P (2007) Vitamin D status predicts physical performance and its decline in older persons. J Clin Endocrinol Metab 92:2058-2065

11. Bouillon R, Marcocci C, Carmeliet G, Bikle D, White JH, Dawson-Hughes B, Lips P, Munns CF, Lazaretti-Castro M, Giustina A, Bilezikian J (2019) Skeletal and extraskeletal actions of vitamin D: current evidence and outstanding questions. Endocr Rev 40:1109-1151

12. Bischoff-Ferrari HA, Can U, Staehelin HB, Platz A, Henschkowski J, Michel BA, Dawson-Hughes B, Theiler R (2008) Severe vitamin D deficiency in Swiss hip fracture patients. Bone 42:597-602

13. Bleicher K, Cumming RG, Naganathan V, Blyth FM, Le Couteur DG, Handelsman DJ, Waite LM, Seibel MJ (2014) U-shaped association between serum 25-hydroxyvitamin $\mathrm{D}$ and fracture risk in older men: results from the prospective population-based CHAMP study. J Bone Miner Res 29:2024-2031

14. Hao L, Carson JL, Schlussel Y, Noveck H, Shapses SA (2020) Vitamin D deficiency is associated with reduced mobility after hip fracture surgery: a prospective study. Am J Clin Nutr 112:613618

15. (2021) National Institutes of Health, Office of Dietary Supplements. Vitamin D: fact sheet for health professionals. In. Available at : https://ods.od.nih.gov/factsheets/VitaminDHealthProfessional/.

16. Holick MF, Chen TC (2008) Vitamin D deficiency: a worldwide problem with health consequences. Am J Clin Nutr 87:1080S$1086 \mathrm{~S}$

17. Willett AM (2005) Vitamin D status and its relationship with parathyroid hormone and bone mineral status in older adolescents. Proc Nutr Soc 64:193-203

18. Ross ATC, Yatkine AL, Del Valle HB (2011) Dietary reference intakes for calcium and vitamin D. National Academic Press, In Washington DC https://www.ncbi.nlm.nih.gov/books/ NBK56070

19. Bischoff Ferrari HA, Keller U, Burckhardt P, Quack Lötscher K, Gerber B, l'Allemand D, Laimbacher J, Bachmann M, Rizzoli R (2012) Recommandations de la Commission fédérale de l'alimentation concernant l'apport de vitamine D. Forum Med Suisse 12: 775-778

20. Chen T, Lu Z, Holick MF (2010) Photobiology of vitamin D. In: Holick M (ed) Vitamin D : physiology, molecular biology, and clinical applications, 2nd edn. Humana Press, New York https:// www.researchgate.net/publication/226691483_Photobiology_of Vitamin D

21. Sempos CT, Durazo-Arvizu RA, Binkley N, Jones J, Merkel JM, Carter GD (2016) Developing vitamin D dietary guidelines and the lack of 25-hydroxyvitamin D assay standardization: the everpresent past. J Steroid Biochem Mol Biol 164:115-119

22. Binkley N, Dawson-Hughes B, Durazo-Arvizu R, Thamm M, Tian L, Merkel JM, Jones JC, Carter GD, Sempos CT (2017) 
Vitamin D measurement standardization: the way out of the chaos. J Steroid Biochem Mol Biol 173:117-121

23. Le Goff C, Peeters S, Crine Y, Lukas P, Souberbielle JC, Cavalier E (2012) Evaluation of the cross-reactivity of 25-hydroxyvitamin D2 on seven commercial immunoassays on native samples. Clin Chem Lab Med 50:2031-2032

24. Vermeulen A, Verdonck L, Kaufman JM (1999) A critical evaluation of simple methods for the estimation of free testosterone in serum. J Clin Endocrinol Metab 84:3666-3672

25. Powe CE, Ricciardi C, Berg AH, Erdenesanaa D, Collerone G, Ankers E, Wenger J, Karumanchi SA, Thadhani R, Bhan I (2011) Vitamin D-binding protein modifies the vitamin D-bone mineral density relationship. J Bone Miner Res 26:1609-1616

26. Nielson CM, Jones KS, Bouillon R, Osteoporotic Fractures in Men (MrOS) Research Group, Chun RF, Jacobs J, Wang Y, Hewison M, Adams JS, Swanson CM, Lee CG, Vanderschueren D, Pauwels S, Prentice A, Smith RD, Shi T, Gao Y, Zmuda JM, Lapidus J, Cauley JA, Schoenmakers I, Orwoll ES (2016) Role of assay type in determining free 25-hydroxyvitamin D levels in diverse populations. N Engl J Med 374:1695-1696

27. Bikle D, Bouillon R, Thadhani R, Schoenmakers I (2017) Vitamin $\mathrm{D}$ metabolites in captivity? Should we measure free or total 25(OH)D to assess vitamin D status? J Steroid Biochem Mol Biol 173:105-116

28. Berg AH, Powe CE, Evans MK, Wenger J, Ortiz G, Zonderman AB, Suntharalingam P, Lucchesi K, Powe NR, Karumanchi SA, Thadhani RI (2015) 24,25-Dihydroxyvitamin $\mathrm{d} 3$ and vitamin D status of community-dwelling black and white Americans. Clin Chem 61:877-884

29. Herrmann M, Farrell CL, Pusceddu I, Fabregat-Cabello N, Cavalier E (2017) Assessment of vitamin D status - a changing landscape. Clin Chem Lab Med 55:3-26

30. Cavalier E, Huyghebaert L, Rousselle O, Bekaert AC, Kovacs S, Vranken L, Peeters S, Le Goff C, Ladang A (2020) Simultaneous measurement of $25(\mathrm{OH})$-vitamin D and 24,25(OH)2-vitamin D to define cut-offs for CYP24A1 mutation and vitamin D deficiency in a population of 1200 young subjects. Clin Chem Lab Med 58: 197-201

31. Priemel M, von Domarus C, Klatte TO et al (2010) Bone mineralization defects and vitamin D deficiency: histomorphometric analysis of iliac crest bone biopsies and circulating 25 hydroxyvitamin D in 675 patients. J Bone Miner Res 25:305-312

32. Yu HJ, Kwon MJ, Woo HY, Park H (2016) Analysis of 25hydroxyvitamin D status according to age, gender, and seasonal variation. J Clin Lab Anal 30:905-911

33. Macdonald HM, Mavroeidi A, Fraser WD, Darling AL, Black AJ, Aucott L, O'Neill F, Hart K, Berry JL, Lanham-New SA, Reid DM (2011) Sunlight and dietary contributions to the seasonal vitamin D status of cohorts of healthy postmenopausal women living at northerly latitudes: a major cause for concern? Osteoporos Int 22:2461-2472

34. Jungert A, Roth HJ, Neuhauser-Berthold M (2012) Serum 25hydroxyvitamin D3 and body composition in an elderly cohort from Germany: a cross-sectional study. Nutr Metab (Lond) 9:42

35. Vimaleswaran KS, Berry DJ, Lu C, Tikkanen E, Pilz S, Hiraki LT, Cooper JD, Dastani Z, Li R, Houston DK, Wood AR, Michaëlsson K, Vandenput L, Zgaga L, Yerges-Armstrong LM, McCarthy MI, Dupuis J, Kaakinen M, Kleber ME, Jameson K, Arden N, Raitakari O, Viikari J, Lohman KK, Ferrucci L, Melhus $\mathrm{H}$, Ingelsson $\mathrm{E}$, Byberg L, Lind L, Lorentzon M, Salomaa V, Campbell H, Dunlop M, Mitchell BD, Herzig KH, Pouta A, Hartikainen AL, the Genetic Investigation of Anthropometric Traits (GIANT) consortium, Streeten EA, Theodoratou E, Jula A, Wareham NJ, Ohlsson C, Frayling TM, Kritchevsky SB, Spector TD, Richards JB, Lehtimäki T, Ouwehand WH, Kraft P, Cooper C, März W, Power C, Loos RJF, Wang TJ, Järvelin MR,
Whittaker JC, Hingorani AD, Hyppönen E (2013) Causal relationship between obesity and vitamin D status: bi-directional Mendelian randomization analysis of multiple cohorts. PLoS Med 10:e1001383

36. Nonnecke BJ, McGill JL, Ridpath JF, Sacco RE, Lippolis JD, Reinhardt TA (2014) Acute phase response elicited by experimental bovine diarrhea virus (BVDV) infection is associated with decreased vitamin D and E status of vitamin-replete preruminant calves. J Dairy Sci 97:5566-5579

37. Waldron JL, Ashby HL, Cornes MP, Bechervaise J, Razavi C, Thomas OL, Chugh S, Deshpande S, Ford C, Gama R (2013) Vitamin D: a negative acute phase reactant. J Clin Pathol 66: 620-622

38. Yamanaka Y, Menuki K, Zenke Y, Ikeda S, Hatakeyama E, Kawano K, Nishida S, Tanaka H, Yumisashi K, Sakai A (2019) Serum 25-hydroxyvitamin D concentrations in Japanese postmenopausal women with osteoporotic fractures. Osteoporos Sarcopenia 5:116-121

39. Nakamura K, Tsugawa N, Saito T, Ishikawa M, Tsuchiya $Y$, Hyodo K, Maruyama K, Oshiki R, Kobayashi R, Nashimoto M, Yoshihara A, Ozaki R, Okano T, Yamamoto M (2008) Vitamin D status, bone mass, and bone metabolism in home-dwelling postmenopausal Japanese women: Yokogoshi Study. Bone 42:271277

40. Awal W, Bindra R, Price N, Sadler A, Robinson A, Hymer I, Chen $\mathrm{J}$ (2020) Vitamin D deficiency in proximal femur fracture patients of South-East Queensland. Australas J Ageing 39:e271-e277

41. Cher EWL, Allen JC, Moo IH, Lo EC, Peh B, Howe TS, Koh JSB (2020) Sub-optimal serum 25-hydroxyvitamin D level affects 2year survival after hip fracture surgery. J Bone Miner Metab 38: $555-562$

42. Dadra A, Aggarwal S, Kumar P, Kumar V, Dibar DP, Bhadada SK (2019) High prevalence of vitamin D deficiency and osteoporosis in patients with fragility fractures of hip: a pilot study. J Clin Orthop Trauma 10:1097-1100

43. Lakkireddy M, Mudavath SV, Karra ML, Arora AJ (2019) Hypovitaminosis D in patients with osteoporotic hip fractures. J Clin Orthop Trauma 10:768-773

44. Niikura T, Oe K, Sakai Y et al (2019) Insufficiency and deficiency of vitamin D in elderly patients with fragility fractures of the hip in the Japanese population. J Orthop Surg (Hong Kong) 27: 2309499019877517

45. Papaioannou A, Kennedy CC, Giangregorio L, Ioannidis G, Pritchard J, Hanley DA, Farrauto L, DeBeer J, Adachi JD (2011) A randomized controlled trial of vitamin D dosing strategies after acute hip fracture: no advantage of loading doses over daily supplementation. BMC Musculoskelet Disord 12:135

46. Ish-Shalom S, Segal E, Salganik T, Raz B, Bromberg IL, Vieth R (2008) Comparison of daily, weekly, and monthly vitamin D3 in ethanol dosing protocols for two months in elderly hip fracture patients. J Clin Endocrinol Metab 93:3430-3435

47. Mak JC, Klein LA, Finnegan T, Mason RS, Cameron ID (2014) An initial loading-dose vitamin $\mathrm{D}$ versus placebo after hip fracture surgery: baseline characteristics of a randomized controlled trial (REVITAHIP). BMC Geriatr 14:101

48. Moo IH, Kam CJW, Cher EWL, Peh BCJ, Lo CE, Chua DTC, Lo NN, Howe TS, Koh JSB (2020) The effect of the comorbidity burden on vitamin D levels in geriatric hip fracture. BMC Musculoskelet Disord 21:524

49. Maier GS, Seeger JB, Horas K, Roth KE, Kurth AA, Maus U (2015) The prevalence of vitamin D deficiency in patients with vertebral fragility fractures. Bone Joint J 97-B:89-93

50. Maier GS, Kolbow K, Lazovic D, Horas K, Roth KE, Seeger JB, Maus U (2016) Risk factors for pelvic insufficiency fractures and outcome after conservative therapy. Arch Gerontol Geriatr 67:8085 
51. Bee CR, Sheerin DV, Wuest TK, Fitzpatrick DC (2013) Serum vitamin D levels in orthopaedic trauma patients living in the northwestern United States. J Orthop Trauma 27:e103-e106

52. Wang N, Chen Y, Ji J, Chang J, Yu S, Yu B (2020) The relationship between serum vitamin D and fracture risk in the elderly: a meta-analysis. J Orthop Surg Res 15:81

53. Aspray TJ, Bowring C, Fraser W, Gittoes N, Javaid MK, Macdonald H, Patel S, Selby P, Tanna N, Francis RM, National Osteoporosis Society (2014) National osteoporosis society vitamin D guideline summary. Age Ageing 43:592-595

54. Brinker MR, O'Connor DP, Monla YT, Earthman TP (2007) Metabolic and endocrine abnormalities in patients with nonunions. J Orthop Trauma 21:557-570

55. Jesudason D, Need AG, Horowitz M, O'Loughlin PD, Morris HA, Nordin BE (2002) Relationship between serum 25hydroxyvitamin $\mathrm{D}$ and bone resorption markers in vitamin $\mathrm{D}$ insufficiency. Bone 31:626-630

56. Pourfeizi HH, Tabriz A, Elmi A, Aslani H (2013) Prevalence of vitamin $\mathrm{D}$ deficiency and secondary hyperparathyroidism in nonunion of traumatic fractures. Acta Med Iran 51:705-710

57. Zura R, Xiong Z, Einhorn T, Watson JT, Ostrum RF, Prayson MJ, Della Rocca GJ, Mehta S, McKinley T, Wang Z, Steen RG (2016) Epidemiology of fracture nonunion in 18 human bones. JAMA Surg 151:e162775

58. Schlundt C, Bucher CH, Tsitsilonis S, Schell H, Duda GN, Schmidt-Bleek K (2018) Clinical and research approaches to treat non-union fracture. Curr Osteoporos Rep 16:155-168

59. Haines N, Kempton LB, Seymour RB, Bosse MJ, Churchill C, Hand K, Hsu JR, Keil D, Kellam J, Rozario N, Sims S, Karunakar MA (2017) The effect of a single early high-dose vitamin D supplement on fracture union in patients with hypovitaminosis D: a prospective randomised trial. Bone Joint J 99-B:1520-1525

60. Doetsch AM, Faber J, Lynnerup N, Watjen I, Bliddal H, Danneskiold-Samsoe B (2004) The effect of calcium and vitamin D3 supplementation on the healing of the proximal humerus fracture: a randomized placebo-controlled study. Calcif Tissue Int 75: 183-188

61. Gorter EA, Krijnen P, Schipper IB (2017) Vitamin D status and adult fracture healing. J Clin Orthop Trauma 8:34-37

62. Gorter EA, Hamdy NA, Appelman-Dijkstra NM, Schipper IB (2014) The role of vitamin D in human fracture healing: a systematic review of the literature. Bone 64:288-297

63. Chiavarini M, Naldini G, Fabiani R (2020) The role of diet in osteoporotic fracture healing: a systematic review. Curr Osteoporos Rep 18:138-147

64. Javed F, Malmstrom H, Kellesarian SV, Al-Kheraif AA, Vohra F, Romanos GE (2016) Efficacy of vitamin D3 supplementation on osseointegration of implants. Implant Dent 25:281-287

65. Nastri L, Moretti A, Migliaccio S et al (2020) Do dietary supplements and nutraceuticals have effects on dental implant osseointegration? A scoping review. Nutrients 12

66. Mangano F, Ghertasi Oskouei S, Paz A, Mangano N, Mangano C (2018) Low serum vitamin D and early dental implant failure: is there a connection? A retrospective clinical study on $1740 \mathrm{im}-$ plants placed in 885 patients. J Dent Res Dent Clin Dent Prospects 12:174-182

67. Dvorak G, Fugl A, Watzek G, Tangl S, Pokorny P, Gruber R (2012) Impact of dietary vitamin D on osseointegration in the ovariectomized rat. Clin Oral Implants Res 23:1308-1313

68. Sprague S, Bhandari M, Devji T, Scott T, Petrisor B, McKay P, Slobogean GP (2016) prescription of vitamin D to fracture patients: a lack of consensus and evidence. J Orthop Trauma 30: e64-e69

69. Anderson PH (2017) Vitamin D activity and metabolism in bone. Curr Osteoporos Rep 15:443-449
70. Foccillo A, Aicale R, Maffulli N (2017) Elective orthopaedic and trauma patients in Southern Italy are vitamin D deficient. A pilot study. Transl Med UniSa 17:6-11

71. Maniar RN, Patil AM, Maniar AR, Gangaraju B, Singh J (2016) Effect of preoperative vitamin D levels on functional performance after total knee arthroplasty. Clin Orthop Surg 8:153-156

72. Maier GS, Horas K, Seeger JB, Roth KE, Kurth AA, Maus U (2014) Is there an association between periprosthetic joint infection and low vitamin D levels? Int Orthop 38:1499-1504

73. Hernigou P, Sitbon J, Dubory A, Auregan JC (2019) Vitamin D history part III: the "modern times"-new questions for orthopaedic practice: deficiency, cell therapy, osteomalacia, fractures, supplementation, infections. Int Orthop 43:1755-1771

74. Maier GS, Maus U, Lazovic D, Horas K, Roth KE, Kurth AA (2016) Is there an association between low serum 25-OH-D levels and the length of hospital stay in orthopaedic patients after arthroplasty? J Orthop Traumatol 17:297-302

75. Mangano F, Mortellaro C, Mangano N, Mangano C (2016) Is low serum vitamin $\mathrm{D}$ associated with early dental implant failure? A retrospective evaluation on 1625 implants placed in 822 patients. Mediat Inflamm 2016:5319718

76. Wagner F, Schuder K, Hof M, Heuberer S, Seemann R, Dvorak G (2017) Does osteoporosis influence the marginal peri-implant bone level in female patients? A cross-sectional study in a matched collective. Clin Implant Dent Relat Res 19:616-623

77. Mears SC, Kates SL (2015) A guide to improving the care of patients with fragility fractures, edition 2. Geriatr Orthop Surg Rehabil 6:58-120

78. Members of the W, Voting panels of the AUCotToHFitE, the AUCoPRoLEHFitE, Quinn RH, Murray JN, Pezold R (2016) The American academy of orthopaedic surgeons appropriate use criteria for management of hip fractures in the elderly. J Bone Joint Surg Am 98:1222-1225

79. Schurch MA, Rizzoli R, Slosman D, Vadas L, Vergnaud P, Bonjour JP (1998) Protein supplements increase serum insulinlike growth factor-I levels and attenuate proximal femur bone loss in patients with recent hip fracture. A randomized, double-blind, placebo-controlled trial. Ann Intern Med 128:801-809

80. Ryan P, Papanek P, Csuka ME, Brown ME, Hopkins S, Lynch S, Scheer V, Schlidt A, Yan K, Simpson P, Hoffman R, Striving to be Strong Team (2018) Background and method of the Striving to be strong study a RCT testing the efficacy of a m-health selfmanagement intervention. Contemp Clin Trials 71:80-87

81. De Vincentis A, Behr AU, Bellelli G et al (2020) Management of hip fracture in the older people: rationale and design of the Italian consensus on the orthogeriatric co-management. Aging Clin Exp Res 32:1393-1399

82. Momosaki R, Kakuda W, Yamada N, Abo M (2016) Impact of board-certificated physiatrists on rehabilitation outcomes in elderly patients after hip fracture: an observational study using the Japan Rehabilitation Database. Geriatr Gerontol Int 16:963-968

83. Monticone M, Ambrosini E, Brunati R, Capone A, Pagliari G, Secci C, Zatti G, Ferrante S (2018) How balance task-specific training contributes to improving physical function in older subjects undergoing rehabilitation following hip fracture: a randomized controlled trial. Clin Rehabil 32:340-351

84. Hawley S, Javaid MK, Prieto-Alhambra D, Lippett J, Sheard S, Arden NK, Cooper C, Judge A, group REs (2016) Clinical effectiveness of orthogeriatric and fracture liaison service models of care for hip fracture patients: population-based longitudinal study. Age Ageing 45:236-242

85. Friedman SM, Mendelson DA, Bingham KW, Kates SL (2009) Impact of a comanaged geriatric fracture center on short-term hip fracture outcomes. Arch Intern Med 169:1712-1717

86. Astrand J, Nilsson J, Thorngren KG (2012) Screening for osteoporosis reduced new fracture incidence by almost half: a 6-year 
follow-up of 592 fracture patients from an osteoporosis screening program. Acta Orthop 83:661-665

87. Neuman MD, Archan S, Karlawish JH, Schwartz JS, Fleisher LA (2009) The relationship between short-term mortality and quality of care for hip fracture: a meta-analysis of clinical pathways for hip fracture. J Am Geriatr Soc 57:2046-2054

88. Adunsky A, Lerner-Geva L, Blumstein T, Boyko V, Mizrahi E, Arad M (2011) Improved survival of hip fracture patients treated within a comprehensive geriatric hip fracture unit, compared with standard of care treatment. J Am Med Dir Assoc 12:439-444

89. Vidan M, Serra JA, Moreno C, Riquelme G, Ortiz J (2005) Efficacy of a comprehensive geriatric intervention in older patients hospitalized for hip fracture: a randomized, controlled trial. J Am Geriatr Soc 53:1476-1482

90. Shyu YI, Liang J, Wu CC, Su JY, Cheng HS, Chou SW, Chen MC, Yang CT (2008) Interdisciplinary intervention for hip fracture in older Taiwanese: benefits last for 1 year. J Gerontol A Biol Sci Med Sci 63:92-97

91. Prestmo A, Hagen G, Sletvold O, Helbostad JL, Thingstad P, Taraldsen K, Lydersen S, Halsteinli V, Saltnes T, Lamb SE, Johnsen LG, Saltvedt I (2015) Comprehensive geriatric care for patients with hip fractures: a prospective, randomised, controlled trial. Lancet 385:1623-1633

92. Moon AS, Boudreau S, Mussell E, He JK, Brabston EW, Ponce BA, Momaya AM (2019) Current concepts in vitamin D and orthopaedic surgery. Orthop Traumatol Surg Res 105:375-382

93. Nawabi DH, Chin KF, Keen RW, Haddad FS (2010) Vitamin D deficiency in patients with osteoarthritis undergoing total hip replacement: a cause for concern? J Bone Joint Surg (Br) 92:496499

94. Matossian-Motley DL, Drake DA, Samimi JS, Camargo CA Jr, Quraishi SA (2016) Association between serum 25(OH)D level and nonspecific musculoskeletal pain in acute rehabilitation unit patients. JPEN J Parenter Enteral Nutr 40:367-373

95. Broe KE, Chen TC, Weinberg J, Bischoff-Ferrari HA, Holick MF, Kiel DP (2007) A higher dose of vitamin d reduces the risk of falls in nursing home residents: a randomized, multiple-dose study. J Am Geriatr Soc 55:234-239

96. Visser M, Deeg DJ, Lips P, Longitudinal aging study A (2003) low vitamin D and high parathyroid hormone levels as determinants of loss of muscle strength and muscle mass (sarcopenia): the longitudinal aging study Amsterdam. J Clin Endocrinol Metab 88: 5766-5772

97. Di Monaco M, Castiglioni C, Di Carlo S, La Marmora E, Filipovic I, Milano E, Minetto MA, Massazza G (2019) Classes of vitamin D status and functional outcome after hip fracture: a prospective, short-term study of 1350 inpatients. Eur J Phys Rehabil Med 55: 56-62

98. LeBoff MS, Hawkes WG, Glowacki J, Yu-Yahiro J, Hurwitz S, Magaziner J (2008) Vitamin D-deficiency and post-fracture changes in lower extremity function and falls in women with hip fractures. Osteoporos Int 19:1283-1290

99. Yao P, Bennett D, Mafham M, Lin X, Chen Z, Armitage J, Clarke $R$ (2019) Vitamin D and calcium for the prevention of fracture: a systematic review and meta-analysis. JAMA Netw Open 2: e1917789

100. Rizzoli R, Boonen S, Brandi ML, Bruyere O, Cooper C, Kanis JA, Kaufman JM, Ringe JD, Weryha G, Reginster JY (2013) Vitamin D supplementation in elderly or postmenopausal women: a 2013 update of the 2008 recommendations from the European society for clinical and economic aspects of osteoporosis and osteoarthritis (ESCEO). Curr Med Res Opin 29:305-313

101. German Nutrition S (2012) New reference values for vitamin D. Ann Nutr Metab 60:241-246
102. (2014) Nordic nutrition recommendations 2012: integrating nutrition and physical activity. . In. https://norden.diva-portal.org/ smash/get/diva2:704251/FULLTEXT01.pdf

103. (2016) European food safety authority. Draft scientific opinion. Scientific opinion on dietary reference values for vitamin D. EFSA In. https://www.efsa.europa.eu/sites/default/files/ consultation/160321.pdf

104. (2016) Public Health England. Scientific advisory committee on nutrition (SACN) vitamin D and health report. In. https://www. gov.uk/government/publications/sacn-vitamin-d-and-healthreport\#: :text=an\%20RNI\%20of\%2010\%20micrograms,aged\% $201 \% 20$ to $\% 204 \% 20$ years

105. Kanis JA, Cooper C, Rizzoli R, Reginster JY, Scientific Advisory Board of the European Society for C, Economic Aspects of O, Osteoarthritis, the Committees of Scientific A, National Societies of the International Osteoporosis F (2019) Executive summary of European guidance for the diagnosis and management of osteoporosis in postmenopausal women. Aging Clin Exp Res 31:15-17

106. Ross AC, Manson JE, Abrams SA et al (2011) The 2011 report on dietary reference intakes for calcium and vitamin $\mathrm{D}$ from the Institute of Medicine: what clinicians need to know. J Clin Endocrinol Metab 96:53-58

107. Holick MF, Binkley NC, Bischoff-Ferrari HA, Gordon CM, Hanley DA, Heaney RP, Murad MH, Weaver CM, Endocrine S (2011) Evaluation, treatment, and prevention of vitamin D deficiency: an Endocrine Society clinical practice guideline. J Clin Endocrinol Metab 96:1911-1930

108. Dawson-Hughes B, Mithal A, Bonjour JP, Boonen S, Burckhardt P, Fuleihan GE, Josse RG, Lips P, Morales-Torres J, Yoshimura N (2010) IOF position statement: vitamin D recommendations for older adults. Osteoporos Int 21:1151-1154

109. Sprague S, Petrisor B, Scott T, Devji T, Phillips M, Spurr H, Bhandari M, Slobogean GP (2016) What is the role of vitamin D supplementation in acute fracture patients? A systematic review and meta-analysis of the prevalence of hypovitaminosis D and supplementation efficacy. J Orthop Trauma 30:53-63

110. Resmini G, Tarantino U, Iolascon G (2013) Vitamin D: role and opportunity to prescribe. Aging Clin Exp Res 25(Suppl 1):S125S127

111. Tripkovic L, Lambert H, Hart K, Smith CP, Bucca G, Penson S, Chope G, Hyppönen E, Berry J, Vieth R, Lanham-New S (2012) Comparison of vitamin D2 and vitamin D3 supplementation in raising serum 25-hydroxyvitamin D status: a systematic review and meta-analysis. Am J Clin Nutr 95:1357-1364

112. Smith H, Anderson F, Raphael H, Maslin P, Crozier S, Cooper C (2007) Effect of annual intramuscular vitamin D on fracture risk in elderly men and women-a population-based, randomized, doubleblind, placebo-controlled trial. Rheumatology (Oxford) 46:18521857

113. Sanders KM, Stuart AL, Williamson EJ, Simpson JA, Kotowicz MA, Young D, Nicholson GC (2010) Annual high-dose oral vitamin $\mathrm{D}$ and falls and fractures in older women: a randomized controlled trial. JAMA 303:1815-1822

114. Bischoff-Ferrari HA, Dawson-Hughes B, Orav EJ, Staehelin HB, Meyer OW, Theiler R, Dick W, Willett WC, Egli A (2016) Monthly high-dose vitamin $\mathrm{D}$ treatment for the prevention of functional decline: a randomized clinical trial. JAMA Intern Med 176: 175-183

115. Rizzoli R (2020) Vitamin D supplementation: upper limit for safety revisited? Res, Aging Clin Exp

116. Antoniak AE, Greig CA (2017) The effect of combined resistance exercise training and vitamin D3 supplementation on musculoskeletal health and function in older adults: a systematic review and meta-analysis. BMJ Open 7:e014619 
117. Chevalley T, Hoffmeyer P, Bonjour JP, Rizzoli R (2002) An osteoporosis clinical pathway for the medical management of patients with low-trauma fracture. Osteoporos Int 13:450-455

118. Klotzbuecher CM, Ross PD, Landsman PB, Abbott TA 3rd, Berger M (2000) Patients with prior fractures have an increased risk of future fractures: a summary of the literature and statistical synthesis. J Bone Miner Res 15:721-739

119. Kanis JA, Johnell O, De Laet C et al (2004) A meta-analysis of previous fracture and subsequent fracture risk. Bone 35:375-382

120. Lindsay R, Silverman SL, Cooper C, Hanley DA, Barton I, Broy SB, Licata A, Benhamou L, Geusens P, Flowers K, Stracke H, Seeman E (2001) Risk of new vertebral fracture in the year following a fracture. JAMA 285:320-323

121. Johansson H, Siggeirsdottir K, Harvey NC, Oden A, Gudnason V, McCloskey E, Sigurdsson G, Kanis JA (2017) Imminent risk of fracture after fracture. Osteoporos Int 28:775-780

122. Torgerson DJ, Dolan P (1999) Advice given to patients with fractures. Drug treatments that reduce fracture rate are underused after vertebral fractures. BMJ 318:1698

123. Hajcsar EE, Hawker G, Bogoch ER (2000) Investigation and treatment of osteoporosis in patients with fragility fractures. CMAJ $163: 819-822$

124. Khan SA, de Geus C, Holroyd B, Russell AS (2001) Osteoporosis follow-up after wrist fractures following minor trauma. Arch Intern Med 161:1309-1312

125. Wilkinson TJ, Sainsbury R, Gilchrist NL (2001) Osteoporosis follow-up after fracture. Arch Intern Med 161:2633

126. Freedman KB, Kaplan FS, Bilker WB, Strom BL, Lowe RA (2000) Treatment of osteoporosis: are physicians missing an opportunity? J Bone Joint Surg Am 82:1063-1070

127. Skedros JG, Holyoak JD, Pitts TC (2006) Knowledge and opinions of orthopaedic surgeons concerning medical evaluation and treatment of patients with osteoporotic fracture. J Bone Joint Surg Am 88:18-24

128. Barton DW, Griffin DC, Carmouche JJ (2019) Orthopedic surgeons' views on the osteoporosis care gap and potential solutions: survey results. J Orthop Surg Res 14:72

129. McLellan AR, Gallacher SJ, Fraser M, McQuillian C (2003) The fracture liaison service: success of a program for the evaluation and management of patients with osteoporotic fracture. Osteoporos Int 14:1028-1034

130. Conley RB, Adib G, Adler RA, Åkesson KE, Alexander IM, Amenta KC, Blank RD, Brox WT, Carmody EE, ChapmanNovakofski K, Clarke BL, Cody KM, Cooper C, Crandall CJ, Dirschl DR, Eagen TJ, Elderkin AL, Fujita M, Greenspan SL, Halbout P, Hochberg MC, Javaid M, Jeray KJ, Kearns AE, King T, Koinis TF, Koontz JS, Kužma M, Lindsey C, Lorentzon M, Lyritis GP, Michaud LB, Miciano A, Morin SN, Mujahid N, Napoli N, Olenginski TP, Puzas JE, Rizou S, Rosen CJ, Saag K, Thompson E, Tosi LL, Tracer H, Khosla S, Kiel DP (2020) Secondary fracture prevention: consensus clinical recommendations from a multistakeholder coalition. J Bone Miner Res 35: 36-52

131. Sujic R, Luo J, Beaton DE, Bogoch ER, Sale JEM, Jaglal S, Jain R, Mamdani M, Ontario Osteoporosis Strategy Fracture S, Prevention Program Evaluation T (2020) Multiple simultaneous fractures are associated with higher all-cause mortality: results from a province-wide fracture liaison service. Osteoporos Int 31: 291-296

132. Marsh D, Akesson K, Beaton DE et al (2011) Coordinator-based systems for secondary prevention in fragility fracture patients. Osteoporos Int 22:2051-2065

133. Lih A, Nandapalan H, Kim M, Yap C, Lee P, Ganda K, Seibel MJ (2011) Targeted intervention reduces refracture rates in patients with incident non-vertebral osteoporotic fractures: a 4-year prospective controlled study. Osteoporos Int 22:849-858
134. Axelsson KF, Jacobsson R, Lund D, Lorentzon M (2016) Effectiveness of a minimal resource fracture liaison service. Osteoporos Int 27:3165-3175

135. Nakayama A, Major G, Holliday E, Attia J, Bogduk N (2016) Evidence of effectiveness of a fracture liaison service to reduce the re-fracture rate. Osteoporos Int 27:873-879

136. Wu CH, Tu ST, Chang YF, Chan DC, Chien JT, Lin CH, Singh S, Dasari M, Chen JF, Tsai KS (2018) Fracture liaison services improve outcomes of patients with osteoporosis-related fractures: a systematic literature review and meta-analysis. Bone 111:92-100

137. Miki RA, Oetgen ME, Kirk J, Insogna KL, Lindskog DM (2008) Orthopaedic management improves the rate of early osteoporosis treatment after hip fracture. A randomized clinical trial. J Bone Joint Surg Am 90:2346-2353

138. Boudou L, Gerbay B, Chopin F, Ollagnier E, Collet P, Thomas T (2011) Management of osteoporosis in fracture liaison service associated with long-term adherence to treatment. Osteoporos Int 22:2099-2106

139. McLellan AR, Wolowacz SE, Zimovetz EA, Beard SM, Lock S, McCrink L, Adekunle F, Roberts D (2011) Fracture liaison services for the evaluation and management of patients with osteoporotic fracture: a cost-effectiveness evaluation based on data collected over 8 years of service provision. Osteoporos Int 22:20832098

140. Solomon DH, Patrick AR, Schousboe J, Losina E (2014) The potential economic benefits of improved postfracture care: a cost-effectiveness analysis of a fracture liaison service in the US health-care system. J Bone Miner Res 29:1667-1674

141. Wu CH, Kao IJ, Hung WC, Lin SC, Liu HC, Hsieh MH, Bagga S, Achra M, Cheng TT, Yang RS (2018) Economic impact and costeffectiveness of fracture liaison services: a systematic review of the literature. Osteoporos Int 29:1227-1242

142. Akesson K, Marsh D, Mitchell PJ, McLellan AR, Stenmark J, Pierroz DD, Kyer C, Cooper C, Group IOFFW (2013) Capture the fracture: a best practice framework and global campaign to break the fragility fracture cycle. Osteoporos Int 24:2135-2152

143. Eisman JA, Bogoch ER, Dell R, Harrington JT, McKinney RE Jr, McLellan A, Mitchell PJ, Silverman S, Singleton R, Siris E, for the ASBMR Task Force on Secondary Fracture Prevention (2012) Making the first fracture the last fracture: ASBMR task force report on secondary fracture prevention. J Bone Miner Res 27: 2039-2046

144. Javaid MK, Kyer C, Mitchell PJ et al (2015) Effective secondary fracture prevention: implementation of a global benchmarking of clinical quality using the IOF Capture the Fracture(R) Best Practice Framework tool. Osteoporos Int 26:2573-2578

145. Saito T, Sterbenz JM, Malay S, Zhong L, MacEachern MP, Chung KC (2017) Effectiveness of anti-osteoporotic drugs to prevent secondary fragility fractures: systematic review and meta-analysis. Osteoporos Int 28:3289-3300

146. Degli Esposti L, Girardi A, Saragoni S, Sella S, Andretta M, Rossini M, Giannini S, on the behalf of the Study g (2019) Use of antiosteoporotic drugs and calcium/vitamin D in patients with fragility fractures: impact on re-fracture and mortality risk. Endocrine 64:367-377

147. Sanli I, van Helden SH, Ten Broeke RHM, Geusens P, Van den Bergh JPW, Brink PRG, Poeze M (2019) The role of the Fracture Liaison Service (FLS) in subsequent fracture prevention in the extreme elderly. Aging Clin Exp Res 31:1105-1111

148. Amouzougan A, Deygat A, Trombert B, Constant E, Denarie D, Marotte H, Thomas T (2015) Spectacular improvement in vitamin D status in elderly osteoporotic women: 8-year analysis of an osteoporotic population treated in a dedicated fracture liaison service. Osteoporos Int 26:2869-2875

149. Chang CB, Yang RS, Chang LY, Peng JK, Tsai KS, Huang WJ, Yang TH, Chan DC (2019) Fracture types affect clinical outcomes 
of patients managed within the fracture liaison and osteoporosis medication management services. Sci Rep 9:10089

150. Nurmi-Luthje I, Luthje P, Kaukonen JP, Kataja M (2015) Positive effects of a sufficient pre-fracture serum vitamin d level on the long-term survival of hip fracture patients in Finland: a minimum 11-Year follow-up. Drugs Aging 32:477-486

151. Cosman F, Nicpon K, Nieves JW (2017) Results of a fracture liaison service on hip fracture patients in an open healthcare system. Aging Clin Exp Res 29:331-334

152. Greenspan SL, Singer A, Vujevich K, Marchand B, Thompson DA, Hsu YJ, Vaidya D, Stern LS, Zeldow D, Lee DB, Karp S, Recker R (2018) Implementing a fracture liaison service open model of care utilizing a cloud-based tool. Osteoporos Int 29: 953-960

153. van Geel T, Bliuc D, Geusens PPM, Center JR, Dinant GJ, Tran T, van den Bergh JPW, McLellan AR, Eisman JA (2018) Reduced mortality and subsequent fracture risk associated with oral bisphosphonate recommendation in a fracture liaison service setting: a prospective cohort study. PLoS One 13:e0198006

154. Lee RH, Pearson M, Lyles KW, Jenkins PW, Colon-Emeric C (2016) Geographic scope and accessibility of a centralized, electronic consult program for patients with recent fracture. Rural Remote Health 16:3440

155. Paskins Z, Crawford-Manning F, Bullock L, Jinks C (2020) Identifying and managing osteoporosis before and after COVID19: rise of the remote consultation? Osteoporos Int 31:1629-1632

Publisher's note Springer Nature remains neutral with regard to jurisdictional claims in published maps and institutional affiliations. 